Virtual Mentor. October 2003, Volume 5, Number 10.

doi: 10.1001/virtualmentor.2003.5.10.hlaw1-0310

Health Law

\title{
In Defense of Exceptions to Confidentiality
}

\section{Defense of the argument that psychiatrists have a responsibility to warn the proper authorities if there is reasonable concern that a patient poses a threat to the safety of others.}

Dudley Stewart, MD

\section{An Examination of Confidentiality in Psychiatry after Tarasoff}

In 1968 two students at the University of California at Berkley, Tatiana Tarasoff and Prosenjit Poddar, met and began dating. Poddar believed the relationship to be more serious than Tarasoff did and became preoccupied and withdrawn when she rejected him. In the summer of 1969 Tarasoff left the country to do field work. Poddar went to the university health service for treatment of his depression.

The psychiatrist at the health service prescribed Poddar a mild anti-psychotic and sent him to a psychologist for outpatient therapy. In these therapy sessions Poddar described fantasies of hurting an unnamed girl. The psychologist also found out from a third person that Poddar had been considering buying a gun and became concerned about Poddar's potential for violence. After consulting with his supervising psychiatrist and the psychiatrist who had initially evaluated Poddar, the psychologist called and wrote the campus police asking them to apprehend Poddar. When the campus police went to Poddar's apartment they found him to be, in their judgment, rational. The police warned Poddar to stay away from Tarasoff but did not take him into custody.

Two months later Poddar went to Tatiana Tarasoff's home. Tarasoff's mother told him Tatiana was not home and asked him to leave. Poddar returned later with a pellet gun and a butcher knife, found Tatiana home alone, and killed her.

Tatiana Tarasoff's parents filed a suit against the university campus police and the health services, arguing that Poddar should have been apprehended and their daughter should have been warned about his threats.

In its final ruling on the case in 1976 the California Supreme Court found that therapists have a duty to protect their patients' potential victims. Various state courts have struggled with how to define the duty a physician may owe patients' potential victims. In general the physician's duty to protect has extended to clearly foreseeable victims of clearly foreseeable threats [1].

\section{Reference}

1. Anfang SA, Appelbaum PS. Twenty years after Tarasoff: reviewing the duty to protect. Harv Rev Psychiatry. Jul-Aug 1996;4:67-76.

View Article $\underline{\text { PubMed }}$ Google Scholar 
In this issue devoted to ethical issues in the specialty of psychiatry we have solicited 2 commentaries that examine confidentiality in the practice of psychiatry after Tarasoff. Commentary 2.

\section{Commmentary}

\section{by Dudley Stewart, MD}

Confidentiality is the cornerstone and a sine qua-non of the patient-psychiatrist relationship. In the American Medical Association's Code of Ethics we reiterate the importance of confidentiality in a manner consistent with our mission "to advocate for our patients, physicians, and the public health."

It is the "public health" concern that has chipped away at the ideal of absolute confidentiality that still exists in priestpenitent interactions. Even attorney-client communications have a "disclosure" element if a crime is about to be committed where injury is likely to occur.

Our AMA's Code of Ethics addresses confidentiality in Principle IV: "A physician shall respect the rights of patients, colleagues, and other health professionals, and shall safeguard patient confidences and privacy within the constraints of the law" [1]. In their current opinions, the AMA's Council on Ethical and Judicial Affairs states that "the obligation to safeguard patient confidences is subject to certain exceptions, which are ethically and legally justified because of overriding social considerations. Where a patient threatens to inflict serious bodily harm to another person or to him or herself and there is a reasonable probability that the patient may carry out the threat, the physician should take reasonable precautions for the protection of the intended victim, including notification of law enforcement authorities" [2].

These public health or social concerns of organized medicine have been traditionally linked to communicable diseases but more recently have been expanded upon by various legislative initiatives that either require or permit disclosure. For physicians the "permissive" statutes are epitomized by the "Tarasoff" doctrine (1974-1976), in which confidentiality may be breached to protect an identified third party from harm. The doctrine has been extended by the courts to even unidentified individuals.

Currently there are 23 states with Tarasoff-type legislation including the state in which I practice, Louisiana [3]. In 1985 Louisiana did not have this legislation and, until revised, it was problematic, as are laws that suggest the "threat" must be "immediate" [4] or "imminent" as in the old American Psychiatric Association ethical guidelines. The current Louisiana law follows the new APA guidelines by suggesting that confidentiality may be breached in cases where there is "a threat that is deemed significant in the clinical judgment of the treating psychiatrist" [5]. These changes in both the Louisiana law and the APA guidelines came about as a result of a lawsuit against a clinical psychologist and myself (Viviano vs Moan et al). We were sued for breaching the confidentiality of a patient by notifying a sitting federal judge, Judge Veronica Wicker, that this patient was stalking her and was planning to kill her and others but not until after his retrial took place. He had previously won a verdict in her court for over \$1 million. After thanking the jury and dismissing them, Judge Wicker had turned to Mr. Viviano and his lawyers and said, "Though I've never done this before, I'm overturning the verdict—because you sued the wrong defendant."

Mr. Viviano first saw Dr. Moan, the psychologist in the suit, shortly after his first trial and then was referred to me for possible medication. His homicidal intent was present from the first, but it intensified over time, and a confluence of events, drug use and abuse, medication noncompliance, and missed appointments made the probability of his carrying out the threat far greater than the probability that he would not do so. He reported to me that he had watched the judge, could see into her home, and knew where she parked; he chronicled her morning "routine," including her "jog." During this time I consulted with colleagues and an attorney experienced in health care law, and notifying the judge was the unanimous recommendation. Involuntary hospitalization was not an option because his "dangerousness" did not flow from a mental illness but rather from his rage at being deprived of his $\$ 1$ million, and his plan was to commit these murders after his upcoming trial.

After an effort to resolve the issue at a deposition where I refused to spell out what he had said in a particular session, a federal magistrate, Michelle Wynn, was called to "settle the issue," but she never returned the call. Three days later, 
after no contact from the federal magistrate, I tried to call Judge Wicker herself but was put off by her clerk. I then hand-delivered a letter to Judge Wicker. Within minutes she was on the phone, and she dispatched the FBI and US marshals to my office, since it is a federal crime to threaten or murder a federal judge.

Subsequently, the FBI arrested Mr. Viviano. He was armed at the time. He was evaluated prior to being transferred to Springfield where he stayed until his trial for attempted murder. He had a hung jury and then pled guilty to obstructing justice, was fined and sentenced to a private psychiatric hospital. Upon release from this facility he sued my psychologist colleague and me for \$10 million for breaching his confidentially.

Though a number of ploys were used by the plaintiff attorney ("it was a dream, it was because of the medication," "it was a joke"), the issue boiled down to the word "imminent" and its definition. The plaintiff said it meant "in the next 10 minutes." We were unable to ascertain what it really meant since the ethics language allowed this threat to stand alone without being evaluated as to credibility, timeliness, or the unpredictability factor.

We won at trial, which took 3 weeks, and occurred after the American Psychiatric Association (APA) passed a change in the language of their ethical code at the Assembly level. The appellate court affirmed the trial court verdict. After the APA Board of Trustees ratified the change, the Louisiana Supreme Court refused to hear the case. The ordeal spanned 7 years and was the first "reverse Tarasoff" case on record.

Retrospectively, I believe that, in the same situation, the same steps need to be taken. Thankfully, the new Louisiana statutes [4] and the revised APA guidelines obviate that dilemma. I couldn't live with the reality of a dead judge and 9 dead attorneys counter-balanced by silence about my rageful patient's intentions with the mistaken belief that his privacy took precedence over the lives of 10 people.

\section{References}

1. American Medical Association. Principle IV of medical ethics. Code of Medical Ethics and Current Opinions, 2002-2003 edition. Chicago: AMA Press; 2002:xii

View Article $\underline{\text { PubMed }}$ Google Scholar

2. American Medical Association, 60-61.

3. Walcott DM, Cerundolo P, Beck JC. Current analysis of the Tarasoff duty: an evolution towards the limitation of the duty to protect. Behavioral Sciences and the Law. 2001;19:325-343.

View Article PubMed Google Scholar

4. LA rs9-2800.2 and 1sA.-RS.9280.2.

5. American Psychiatric Association. Section 4, paragraph 8. The Principles of Medical Ethics with Annotations Especially Applicable to Psychiatry,Section 41995 ed. Chicago: APA Press; 1995:6. Google Scholar

Note: In December 1994, the Board of Trustees of the APA Assembly voted to change section 4, annotation 8 of The Principles (regarding duty to warn) from its current wording to the following: "When in the clinical judgment of the treating psychiatrist, the risk of danger is deemed to be significant, the psychiatrist may reveal confidential information disclosed by the patient." This change was printed in the 1995 edition of The Principles, but for unexplained reasons all subsequent editions including the 2001 edition have reverted to the original language. This is being corrected. Contact Linda Hughes at the American Psychiatric Association, 1-888-357-7924, with questions.

Dr. Dudley Stewart, MD, is a board-certified psychiatrist who has been in practice in New Orleans for over 30 years. The events chronicled in this report took place before he was appointed to the AMA's Council on Ethical and Judicial Affairs in June of 2003. 
The viewpoints expressed on this site are those of the authors and do not necessarily reflect the views and policies of the AMA.

(C) 2003 American Medical Association. All Rights Reserved. 